\title{
CHAIRS AS STRUCTURES IN EGON SCHIELE'S AESTHETICS. EGON SCHIELE'S PLACE IN WITTGENSTEIN'S VIENNA
}

\author{
Carla Carmona Escalera \\ Universitad de Sevilla
}

\begin{abstract}
This paper is part of a larger project that tries to give to Egon Schiele's oeuvre the place it deserves in what was called by Allan Janik and Stephen Toulmin 'Wittgenstein's Vienna'. We intend to establish certain correlations between Schiele's aesthetic vision and Ludwig Wittgenstein's philosophy. We share the interdisciplinary approach of Janik and Toulmin. Just as they got close to Wittgenstein's philosophical problems by taking into account the historical, philosophical and cultural context to which he belonged, we make use of Schiele's contemporary investigations in different areas of knowledge in order to get a more adequate account of his paintings. Following Wittgenstein's mostly ignored move towards art criticism, we will proceed our investigation through a close analysis and critique of a selection of paintings. Specifically we will be studying Schiele's use of chairs, understanding them as a compositional device of his pictorial language. The aim of this article is to show how his use of chairs illustrates some of the battles fought by his contemporaries.
\end{abstract}

Keywords.- Wittgenstein, Schiele, use, form of life, pictorial grammar

This paper looks closely into the role played by chairs in Egon Schiele's pictorial oeuvre in order to propose certain correlations between his aesthetic vision and that of his contemporaries, especially that of Wittgenstein. We believe that the painter's oeuvre has not been given the place it deserves in what was called by Allan Janik and Stephen Toulmin 'Wittgenstein's Vienna ${ }^{1 '}$. We propose that Schiele was on the frontlines of the battle between saying and showing specified by Wittgenstein in the Tractatus Logico-Philosophicus ${ }^{2}$, as much as other figures, such as Adolf Loos, Arnold Schönberg or Karl Kraus, already acknowledged for it $^{3}$.

Most of the studies on Schiele's works have been intrinsically linked to biographical interpretations ${ }^{4}$; furthermore, they have been done from the perspective of Art History and not from Philosophy. This paper, leaving aside his personal life and starting from the self-representation ${ }^{5}$ characteristic of all works of art, takes his oeuvre as a whole and analyses it as such: helping ourselves only from what is there in his pieces. We share the approach of Kimberly A. Smith while facing Schiele's landscapes in Between Ruin and Renewal: Egon Schiele's Landscapes ${ }^{6}$. By analysing Schiele's paintings, we try to place his oeuvre in his cultural background, starting from the idea that the former is a product of the latter and vice versa. However, on the one hand, we have tried to face the whole of Schiele's oeuvre and not just his landscapes, and, on the other hand, we will study the ethical dimension of his work. In order to do the latter, we will focus on Wittgenstein's philosophy because we consider that its ethical dimension is representative of his contemporaries' ethics. We agree with Smith that Schiele's landscapes have been ignored by the painter's 
specialists because their research has focused on his life, revolving around the myth of genius, instead of on the historical context in which his oeuvre flourished ${ }^{7}$. But his landscapes were not the only ones left out. Main aspects of his well-known and vastly discussed portraits have been ignored. For instance, the very pictorial syntax which constitutes them.

$w_{e}$ are going to stay within Wittgenstein's philosophy to do what we attempt. Our work has as a base the Wittgensteinian notion of lebensform: an allembracing and comprehensive understanding of reality shared by the members of a linguistic community in a specific point of time ${ }^{8}$. If in order to understand aesthetic expressions, one has to describe ways of living ${ }^{9}$, the same is needed for understanding works of $\mathrm{art}^{10}$. A form of life is the given, what we can only accept $^{11}$. It is the place that gives shelter to language, as the human face does to the smiling mouth ${ }^{12}$. Our procedure, furthermore, will be Wittgensteinian: ours will be an aesthetic investigation that will make use of descriptions, comparisons and examples to get to its goal. However we are not going to do what is generally understood as Wittgensteinian Aesthetics. We are not interested in analysing verbal language on art, but the language of art in itself. By the language of art we mean the structures and other compositional devices that lead to the coherence of a particular piece and of an oeuvre as a whole.

Although Wittgenstein in his most well-known work on aesthetics focused on the analysis of verbal language13, he pointed out in his aesthetic lecture included in "Philosophy for Mathematicians"14 and in the Manuscript 156a (MS 156a) from 1932-415 that reflecting on a specific work of art was a valid approximation towards the aesthetic enquiry 16 . Moving towards art criticism, the philosopher called our attention to the need to place things side by side17 and to give reasons of the kind for having a word rather than other one in a particular place in a poem18, always drawing our attention to specific features and describing by comparisons 19 .

We are trying to look in painting for what Schönberg called in music the musical $i d e a^{20}$. We intend to get to the bottom of Schiele's syntax, of his art of pictorial composition. We will analyse Schiele's pictorial 'language games' (his games of line, colour and composition) taking into account that the meaning of a term is conferred by usage - that meaning is something to be filled, understanding each painting by the artist as an 'activity' or 'occasion' that confers meaning to what takes place within it. It is the precision of his syntax what enables his paintings to show their limits. In this paper, we are going to study the role of chairs, which we understand as a structural device in Schiele's oeuvre. We will try to give reasons that explain why in some cases Schiele's figures sit on a chair and in other cases they don't need the seat to sit themselves. We propose that his use of chairs portrays many of the struggles that the Austrian painter shared with his contemporaries, particularly with Wittgenstein. Our analysis aims at letting the pictorial chairs themselves show those connections.

At first glance it seems difficult to talk about structures in the work of Schiele. However, if we pay attention to Mother with two children III (1917, Vienna, 
Österreichische Galerie Belvedere), we realize that the relationship between the three figures and the background is not direct. Taking into consideration the sketches on paper that Schiele executed before facing the canvas ${ }^{21}$, this becomes more obvious. What mediates between the two dimensions? We will answer this question through a tour along different pieces, analysing their structures, the mediators, till we are able to confront the mentioned work, which we understand as almost a suitable example for the Wittgensteinian maxim 'meaning is in usage'.

Many times what acts as a mediator between the figure and what surrounds it is a chair, an ordinary device in the history of portrait ${ }^{22}$. Schiele creates all kinds of chairs. In the painting Portrait of the painter Paris von Güterlosh (1918, Minneapolis, The Minneapolis Institute of Arts), background and chair are perfectly harmonized thanks to the fact that the painter uses the same palette for both and to the vaguely defined seat, which could be considered as a plane more in the background. The main achievement of this piece of work is the unification of a background of three planes (vertical-wall, horizontal-ground and chair) and a figure that, on the one hand, is openly dealt with in more detail and, on the other hand, which palette differs from the one of the other elements. This is managed thanks as much to the common spontaneity to the application of colour and the line as to the echoes of the surrounding colours created on the sitter's clothes and skin.

Let's observe first the lower half of the painting. We realize how in spite of the strong cutting line with which Schiele erects his figure's legs, these are one with what surrounds them. First of all, the trousers, due to the orangey, brownish and greenish shadows and reflections, share the shades of the background. Secondly, the trousers' wrinkles seem to serve the internal structure of the pants. Likewise, the arrangement of the chosen colours, earthy, is absolutely balanced in the canvas. Dark brown in the external side of each leg. Lemongarish-orange beside the foreshortened thighs. On the right, less brown and more orange; on the left, the opposite. They are explosions of colour: colour, just as the wrinkle-line, seems to emerge from the canvas, instead of having been applied, as little flowers obeying the internal principles of the composition. In the upper part of the canvas, we find two opposite, but balanced forces. Firstly, the echoes of the colours from the background on the sitter's shirt favours the compositional coherence; besides, the resultant white colour is cleaner than the one on the trousers, which, together with the absolutely lineal and detailed treatment of the tensioned hands, reminds us of the figure's limits in relation to the whole.

Nevertheless, his chairs do not always act as a bridge between figure and background. There are paintings in which one does not have such a feeling of unity, given that the chairs offered to his figures are clumsy, stiff, of right angles unable to live together with the chameleonlike character of the figures. Schiele painted seats in only three periods of his life: during his first (Secessionist) stage, in prison and from a portrait he made of his father-in-law in 1916 onwards. Many of the cases in which chairs and figures do not match are from the last year of Schiele's life, as the portraits of Hugo Koller (1918, Vienna, Österreichische Galerie Belvedere) and Victor Ritter von Bauer (1918, Vienna, 
Österreichische Galerie Belvedere). Therefore, it is not a question of poor technique.

Both the paintings mentioned in the previous paragraph were commissions; that means, Schiele was not directly interested in these gentlemen and would not have portrayed them had he not been paid for it. As Gustav Klimt did, Schiele became a painter of the middle and upper class society in the last years of his life $^{23}$. This poor interest could explain the characteristic lack of integration of these paintings. For instance, the latter one could even be considered unfinished, since the minimum of coherence always required is not fulfilled. It is interesting that he went back to the seat, such an early element in his work, while having to portray something so far away from him. In none of these cases does the chair achieve its assumed aim: the integration of the figure in the canvas. In fact, it highlights the distinction between figure and background, underlining the superposition of the first one. This representation of the chair makes this instrument work differently from how it functions in the paintings discussed earlier. Wittgenstein stated in the Philosophical Investigations that the meaning of a single word cannot be established in isolation since it lies in how that word is used in a given context. The same could be said of a chair: its meaning cannot be said because it depends on the context and it could only be shown in and through the latter. As Wittgensteinian 'language games' show that the meaning of words is in their use, our painter's works, also 'language games', show that the meaning of each chair lies in how it is used on a particular canvas.

Either clumsy or subtle, chairs are there. Schiele was so aware of the being there of the chair that he even depicted them as entities, free from the seated ones, as happens in several drawings he did while in prison. Let's look at Art Cannot Be Modern; Art Is Primordially Eternal (1912, Vienna, Albertina). We understand these chairs as Heideggerian utensils whose beings erect on the piece of paper thanks to the astonishment provoked by the work of $\mathrm{art}^{24}$. Applying to these chairs what Heidegger stated about the work of art speaking of Vincent Van Gogh's A Pair of Shoes (1886, Amsterdam, Van Gogh Museum) in his oeuvre The Origin of the Work of $\mathrm{Art}^{25}$, we claim that these drawings by Schiele teach us the truth of a chair. The artist tried to reach the being of a chair as he had attempted till then the being of his figures. It is understandable that Schiele related to chairs as he did earlier to figures, since in prison the former were his only companions. Chairs are forced to the same perspectives than those wonderful nudes carried out in 1910 - as the canvas Seated Male Nude (1910, Vienna, Leopold Museum) analysed later - and survived them with liveliness, adapting themselves to the environment. In the drawings done in prison, just as in those nudes, the background (the colour of the paper) is, at its most, a plane, since in the last case one cannot even talk about it as a supporting surface, given that the chair and the jar do not clearly indicate its direction.

The rigidity about which we talked about before reaches its maximum expression in what could be considered X-ray-chairs. Let's look at Portrait of the Artist's Wife, Seated (1918, Vienna, Österreichische Galerie Belvedere). It was not a commission. The figure is clearly separated from the background, but it is 
so not thanks to the chair, which looks like a bad attempt to justify the being seated of the figure. The chair has received a similar treatment to the background: both of very dark shades, although in the former the strokes are smaller and the greenish shades predominate. The painter insinuates the distinction between chair and background by means of a kind of black halo which surrounds the former, an outline which sometimes merges with the latter and the introduction of yellow shines. This chair does not have any kind of character. If we go back to the ones he depicted in his cell, we do not find anything in common among them. The statement 'they are equal', the fact that they fit in the same drawer, brings out the poverty of our concepts; it is like suggesting that a human being and a doll with the shape of a human being belong to the same species. There is nothing left of the being-chair of this chair. One can only refer to it as a caricature, a mask or an X-ray ${ }^{26}$. In fact, under the label 'chair' we only find the X-ray of a chair. Friedrich Nietzsche already proposed it in his 1873 essay On Truth and Lie in an Extra-Moral Sense ${ }^{27}$ : a concept is just a worn-out metaphor. In order to serve as a concept, a word has to leave aside all attempts to portray that individual experience to which it owes its own existence and fit innumerable 'similar' cases. With this chair, the Austrian painter gives us back our concept 'chair', highlighting how human beings have to choose between concepts and particular entities, since, paraphrasing Nietzsche, all concepts are formed making equal the non-equal. Therefore, not only is the world scattered in fragments: those considered identical are not. Schiele's oeuvre offers an alternative to the violence exercised by ordinary language. His diverging depictions of a chair question the universal pretensions of the concept 'chair' and establish that among all the entities we call chairs there are only Wittgensteinian family relations.

Let's continue on our path. There are other cases, ornament-chairs, in which even if the seat occupies a large part of the compositional space, the chair does not function as such and it cannot be stated that it is 'there'. They belong to the first stage, heavily Secessionist, in Schiele's oeuvre. Let's look at the 1909 portraits of the painters Anton Peschka (1909, New York, Galerie St. Etienne) and Hans Massmann (1909, Zug, Kunsthaus Zug). Not only does the seat in the first case have the same bi-dimensional treatment as the abstract zones in Gustav Klimt's paintings, but the one who preceded our artist painted seats in that way years before, as in Portrait of Fritza Riedler (1906, Vienna, Österreichische Galerie Belvedere). Klimt used to treat some parts of his paintings bi-dimensionally, like dresses, headdresses or seats. The opposition between the bi-dimensional and the three-dimensional is spread across all of Klimt's mature oeuvre; in fact, we also find it in his landscapes, where even if the trees' crowns are bi-dimensional, there is depth, thanks to their trunks ${ }^{28}$.

Although Schiele had not yet developed at the time of these paintings his later control over volume, the confrontation between the bi-dimensional seats and the three-dimensional figures is obvious. The seat, far from being an instrument being used, is a device, mere ornamentation that is not there for itself, but as a complement to the specific posture that the sitter holds. It is not the seat that imposes the posture, but the opposite. Had the artist decided to depict Anton Peschka with his arms slightly more elevated, he would have made the armchair taller. Had he been interested in a more reclined figure, he would have 
exaggerated the curve of the armchair's back. These changes would not mean anything to the armchair. This ornament-chair, absolute appearance, opposes what Loos said about how objects had to be designed according to how they were going to be used. Kraus assessed that what differentiated Loos and him from the 'positive spirits' was that while they distinguished between a urinal and an urn, the latter used the urinal as the urn and vice versa indiscriminately ${ }^{29}$. Just as Wittgenstein found the meaning of a word in its use, Loos understood that a building had to be designed according to its functional dimension. Usage is at the core of both words and architecture.

Loos fought with Kraus's razor the clichés about taste prevalent in Old Vienna ${ }^{30}$. His criticism was mostly directed to the Jugendstil urge to build up a style out of a collection of mostly archaeological ornaments in which the pieces considered the most exquisite were new ornamental 'inventions' that according to Loos proved to be the source of their cultural collapse ${ }^{31}$. Furthermore, this enterprise was based on the illusion that Austria was in need of a style. The Secession was trying to fill a non-existent gap with their non-substantial ornaments. In order to avoid this kind of architectural misuse, Loos insisted on the distinction between art and utility that led him to state that an architect should not be an artist but a craftsman. Paraphrasing what Loos said in "Rules for Building in the Mountains"32, an architect should not think of the roof of a building but of the rain and the snow. In other words, a roof should be designed according to its function: to protect people from the climatic conditions of a particular place. In the same way, a chair should be shaped according to the precise way in which the people from a particular culture sit. Going back to the painting that led to this discussion, the armchair on which our painter made Peschka sit should have been built according to this principle, quite independent of whether the composition looked better. Given that the Viennese architect took objects as signs of the way of life of a particular society, the only changes in a society's instruments that he thought of as appropriate were those caused by modifications in the ways of life of that society.

We also find well-defined chairs that are being used clearly, like in Secession; 49. Ausstellung (1918, Vienna, Albertina), the poster for the Secession Exhibition that Schiele executed in 1918. In this case chairs are being used by a group of books-devouring-commensals sitting around a table. The introduction of the table underlines the fact that the protagonists are sitting down, since they are not just seated, but sitting at a table. These chairs provide a context. Schiele portrayed himself next to a group of his colleagues in this poster, where chairs offer them a place to concentrate upon and from which to leave, that is, an origin. On the one hand, the sitters do not seem independent of their respective chairs. There is something in common between how seats are depicted in this piece and the Aristotelian conception of 'natural place'33. Just as in Aristotelian physics all bodies move towards their 'natural place' and come to a rest when they find it, these figures seem to have already reached the place natural to them: their chair. Each chair, while constituting him, is a home to its guest. This interdependence between figure and chair is also shown through the equal pictorial and lineal treatment that they get. Their respective approaches, schematic to the extreme, seem to respond to the same compositional force. They exchange colours or enjoy identical shades. The 
figure in the lower left corner is reddish-earth and its chair tends to an oxidisediron-yellow similar to the colour of the tunic of the man sitting at his left. There are gentlemen dressed in white seated on white chairs and other seats of the same orange as the one in the dress and the chair of the host, Schiele. On the other hand, although all of them are together, sitting at the same table, each one of them has its own place, very well-defined by the structure-chair that he is using. The structure, apart from providing a place, creates it; it erects (es stellt auf) it, as Heidegger would say of the work of art. In the lower extreme there are two empty seats (the central one has been read as the place left by the already dead Klimt -the artist had died just before Schiele made the poster). In front of the unoccupied chairs, two opened books join the scream of the chairs that demand to be used. Their cry is so powerful that enough presence is conferred upon the chairs to use themselves.

Finally we can face the painting from which we started, Mother with Two Children, where the figures themselves are chairs: chair-figures ${ }^{34}$. One can observe in the lower corners of the painting two legs of a chair invisible to us (the one in the left is much more visible than the one in the right, since the part that is possible to see of this one, if thicker, it is shorter and a shadow is cast over it) which melt with the clothes from the different cloaks and clothing in which the figures are wrapped till the point where they seem inseparable from them. The result from this bound mass is the feeling that the legs are parts of the upholstery-figures; they seem to belong to them. Helped by these clumsy legs and the decorative motifs of their clothes $^{35}$, the figures serve themselves as chairs. The outcome of the subtle illumination of the background just in the outlines of the figures is a halo that makes us think of a ghostly back ${ }^{36}$ for this eccentric chair. The fact that the whole set responds to a triangular composition (as it can be observed in the sketch ${ }^{37}$ ) emphasizes its structural function, given that there is no structure stronger than a triangle. All this makes the chair latent.

However, there is a step further on this path. There are cases in which, although there is no trace left of the chair, its use, the being seated, is clearly depicted, as it happens in many of the portraits and self-portraits that Schiele executed in 1910 (when he developed his own style). See, for example, Portrait of the Publisher Eduard Kosmack (1910, Vienna, Österreichische Galerie Belvedere), Portrait of Arthur Roessler (1910, Vienna, Historisches Museum der Stadt) and Seated Male Nude. In the three paintings, although there is no chair, the figures are seated. Schiele introduced well-defined horizontal and vertical axis in his figures to manage this. In 'Seated Male Nude', the thighs indicate the horizontal plane of the chair and the torso the one of its back. The extreme perpendicularity of the upper and lower halves of the figure (the same thing happens in the other two paintings) cannot be natural, but a result of a (extremely rigid) chair of which only the way in which the figure uses it is left (or maybe the footprints of how the device used the figure). As he did in Portrait of Arthur Roessler, in Seated Male Nude Schiele "sent" the figure's legs in perpendicular directions and, at the same time, both of them are perpendicular to the plane indicated by the torso. Our painter's dreadful academic résumé notwithstanding, it seems that he learnt something from his early forays into mathematics, given that this nude incarnates the familiar $X Y Z$ coordinate system. The first thing he has to do in order to use what is not there is to erect 
the space where it is going to be used and Schiele manages this by creating such directions in the same figure. The figure, on the one hand, is constituted by her usage (as if she was carrying the chair inside herself) and, on the other hand, gives birth to the space, the context, where she will be able to live it (her use of the chair). In Portrait of the Publisher Eduard Kosmack, the directions of the thighs are not perpendicular, but parallel. Although the configuration of the figure is weaker than in the previous cases, the feeling of space is kept due to the confined posture of the publisher, whose torso, a bit more stooped than the ones studied before, seems to tend to his knees, especially due to the shoulders' inclination, raising (again) a 'place'.

Loos put forward an inversely proportional relationship between a people's urge to decorate and their cultural development: so the more primitive a people are, the more ornaments they will have ${ }^{38}$. The Viennese architect took freeing beauty from all ornaments as one of the main aims of mankind. In many of the portraits that Schiele did between 1910 and 1915, the painter radicalised this idea, given that he depicted how an object was used leaving the device itself aside. He did not paint the chair but the action of being seated. And there is no greater nudity than the one of the object that is not physically there while its use is portrayed in the painting. There is no latent chair left. The artist captures in these paintings the force that holds each structure: use.

We consider the tour that has just been completed as a small-scale battlefield in which saying and showing have measured their forces. It illustrates some of the conflicts that Schiele's contemporaries had to face in order to be true to their ethical demands. Not all the paintings discussed belong to the same category. Some of them are more consistent with Schiele's contemporaries' urges than others. If what we have called ornament-chairs represent what Loos wanted to move away from in his struggle against ornament, the last three paintings discussed reach the freedom from ornamentation that maybe Loos himself was not able to achieve in architecture. The different ways in which the young painter depicted chairs are an illustration of the fact that among all of what we call chairs there are only Wittgensteinian family relations. Schiele did not impose any concept on the entities he depicted and did not attempt any definition. It would be hard to find something closer to Wittgenstein's maxim: 'the meaning of a word is in its use'. Furthermore, the painter radicalised Wittgenstein's idea by means of painting "use" itself.

1 (1973) JANIK, Allan \& TOULMIN, Stephen, Wittgenstein's Vienna, Touchstone, New York.

2 (1980) WITTGENSTEIN, Ludwig, Tractatus logico-philosophicus, Schriften 1, Suhrkamp, Frankfurt am Main, pp. 7-83. In this treatise the philosopher set the limits of the sayable, searching for the maximum rigour. About the unsayable he remained as silent as he 
was able to be then. His rigorous saying, aware of its limits, pointed towards the unsaid, showing it (although he did not speak about the most important, it was present as the limit of what was said). He tried to free his saying from any totalizing character. Reaffirming its renunciation to the mystical, saying turned into an infinite diversity of games in the Philosophical Investigations (Philosophische Untersuchungen, Schriften 1, pp. 279-455.

3 The opposite was proved wrong long ago by the following substantial and already classic studies: Janik and Toulmin, Wittgenstein's Vienna; (1978) CACCIARI, Massimo, Krisis: saggio sulla crisi del pensiero negativo da Nietzsche a Wittgenstein, Feltrinelli, Milan; (1997) CACCIARI, Massimo, Posthumous People: Vienna at the Turning Point, trans. Rodger Friedman, Stanford University Press, California; (1980) SCHORSKE, Carl E., Fin-de-siècle Vienna, Politics and Culture, Alfred A. Knopf, New York.

$4 \quad$ We believe these works to be inadequate because they pay more attention to Schiele's life than to his oeuvre. Let's remember Powell's remark on (1974) COMINI, Alessandra, Egon Schiele's Portraits, University of California Press, California: a more appropriate title for the book would have been 'Schiele seen through his portraits', (1976) POWELL, Nicolas, "Egon Schiele, review of Alessandra Comini's Egon Schiele's Portraits", Burlington Magazine, 118, no879, p. 439. About the invalidity of the merely biographical approach and the actual state of research on the artist, cf. (2004) SMITH, Kimberly A., Between Ruin and Renewal: Egon Schiele's Landscapes, Yale University Press, New Haven, pp. 1-7.

However, all people interested in Schiele owe what they know of his life and his artistic career mainly to three authors who studied them in detail: Comini, Kallir and Nebehay. Two crucial examples: Kallir produced the most complete catalogue raisonné of Schiele's oeuvre ((1990) KALLIR, Jane, Egon Schiele. The Complete Works. Including a Biography and a Catalogue Raisonné, with an essay by Wolfgang G. Fischer, Harry N. Abrams, New York, and Nebehay recompiled in 1979 all the documentation related to Schiele known till then in just one book, (1979) NEBEHAY, Christian M., Egon Schiele, 1890-1918: Leben, Briefe, Gedichte, Residenz Verlag, Salzburg.

$5 \quad$ In Wittgenstein's words: "The work of art does not seek to convey something else, just itself" ("Das Kunstwerk will nicht etwas anderes übertragen, sondern sich selbst"), (2006) WITTGENSTEIN, Ludwig, Vermischte Bemerkungen. Eine Auswahl aus dem Nachlas/ Culture and Value. A Selection from the Posthumous Remains, 2nd rev. ed. with English translation), ed. Georg Henrik von Wright in collaboration with Heikki Nyman, revised by Alois Pichler, trans. Peter Winch. Basil Blackwell, Oxford, p. 67.

$6 \quad$ Smith, 2004. Therefore, far from looking down on the perspective of Art History, we are underlining the lack of a philosophical approach to this issue. The philosophical approaches have been short and tangential. If Janik acknowledged Schiele as a brother to George Trakl (Allan Janik, "Review of Egon Schiele: Art, Sexuality and Viennese Modernism", Central European History, 28, no. 1, (1995): 99), who, according to him, played a crucial role in the finde-siècle laboratory, he never focused on Schiele's oeuvre. Leaving aside the differences of approach, this is also the case of Cacciari's work, who indicated that Schiele also shared his contemporaries' urges (Cacciari, Krisis, 1978) and dedicated a short section to him, while establishing the connection between him and Trakl (Cacciari, 1997, pp. 135-9). Schorske, who focused on Klimt and Kokoschka (Schorske, Fin-de-siècle Vienna, 208-78, 322-66) practically did not mention Schiele. Although Casals focused directly on him, his comments do not differ from what was previously said by Janik and Toulmin, Schorske and Cacciari (Josep Casals, Afinidades vienesas (Barcelona: Anagrama, 2003), 426-446).

$7 \quad$ Smith, Between Ruin and Renewal, 6.

8 We have used Kjell S. Johannessen's adjectives, who explains with an enviable clarity the concept in Kjell S. Johannessen, "Rule Following, Intransitive Understanding and Tacit Knowledge (An Investigation of the Wittgensteinian Concept of Practice as regards Tacit Knowing)", Daimon 2, (1990): 168-9.

9 (1983) WITTGENSTEIN, Ludwig, Lectures and Conversations on Aesthetics, Psychology and Religous Belief, ed. Cyril Barrett, compiled from notes by Yorick Smythies, Rush Rhees and James Taylor, Basil Blackwell, Oxford, p. 8; p. 11.

10 Hagberg shows precisely this very well in relation to Raphael's fresco painting The school of Athens in (1994) HAGBERG, Garry, Meaning and Interpretation: Wittgenstein, Henry James and Literary Knowledge, Cornell University Press, Ithaca, pp. 79-80.

$11 \quad$ Wittgenstein, 1980, p. 539.

12 Ibid., $§ 583$. 
13 Lectures and Conversations on Aesthetics, Psychology and Religious Belief.

14 We will be using Moore's transcription, (1959) MOORE, George Edward, Philosophical Papers, Allen \& Unwin, London, pp. 312-15.

15 WITTGENSTEIN, Ludwig, Wittgenstein Source: Bergen Facsimile Edition, ed. Alois Pichler in collaboration with H.W. Krüger, D.C.P. Smith, T.M. Bruvik, A. Lindebjerg and V. Olstad. Wittgenstein Archives at the University of Bergen, Uni Digital.

16 Johannessen has pointed out this second route in his study on the field of application of Wittgenstein's aesthetics, (2004) JOHANNESSEN, Kjell S., "Wittgenstein and the Aesthetic Domain", in Wittgenstein, Aesthetics and Philosophy, ed. Peter Lewis, Ashgate, Aldershot, pp. 13-24.

17 Moore, Philosophical Papers, p. 315.

18 Ibid., p. 314.

19 MS 156a, pp. 53-4 (Wittgenstein, BFE).

20 Schönberg, as Loos did in architecture, put forward that music could not be subordinated to any external structure. He proposed that the only crucial thing in a musical piece is its structure, the musical idea, cf. (1984) SCHÖNBERG, Arnold, Style and Idea. Selected Writings of Arnold Schönberg, ed. Leonard Stein, University of California Press, Berkeley, p. 123.

21 Kallir, Egon Schiele. The Complete Works, pp. 28, 77, 80-5, 87, 90-4, 105, 125.

22 Diego Velázquez's Portrait of Pope Innocent $X$ (1650, Rome, Galleria Doria-Pampili), as well as all the different studies after that painting that Francis Bacon did during his lifetime three centuries later, is a landmark in what could be addressed as a history of the use of seats in portraiture.

23 Nevertheless, Schiele did not portray only the upper class, as Klimt did. (Schiele, as much as Oskar Kokoschka, recorded the living conditions of the Austrian lower classes. Schiele portrayed many poor children and families, as in Mother with Two Children). Furthermore, his pictorial approach, as that of Kokoschka, opposite to Klimt's stylization, is consistent with such living conditions. In spite of Klimt's good intentions, given that he claimed to paint for all, there is no doubt that his was an art for the rich. Looking at Viennese fin-de-siècle photographs, one is completely taken aback by the abyss that stands between them and the Secession building or Klimt's paintings. In fact, after the controversy caused by the panels for the University and the Beethoven Freeze, Klimt gave up all public pretension, openly dedicating himself to the art for a few. This new posture was reflected in his Nuda Veritas, where he included the famous quotation by Schiller.

24 The captured Schiele also did this with other utensils-tools, as his bed, the cell's door, the brooms and the cleaning buckets.

25 (1993) HEIDEGGER, Martin, Basic Writings: from Being and Time (1927) to the Task of Thinking (1964), ed. David Farrell Krell, Harper Collins, New York, 139-212.

26 The same could be said about the figure, so rigid that it looks like a doll. The doll-like figures of the artist are well-known -for example, in Two Girls, Lying Entwined (1915, Vienna, Albertina) the right-hand face looks like the one of a toy. We study them elsewhere.

27 (2009), NIETZSCHE, Friedrich, Friedrich Nietzsche: Writings from the Early Notebooks, ed. Raymond Geuss and Alexander Nehamas, trans. Ladislaus Löb, Cambridge University Press, New York.

28 On the study of the bidimensional in Klimt's landscapes, cf. (2006) KOJA, Stephan (ed.), "Absolutely engulfed in the Beauty of Illusion", Gustav Klimt: Landscapes, ed. Stephan Koja, Prestel, London, pp. 37-8. This differentiation is full of meaning: Klimt used the opposition to distinguish between the ideal and the real (Ibid., 46 (footnote no. 33)).

29 (1987) KRAUS, Karl, Schriften, vol. 8, Suhrkamp, Suhrkamp, p. 341.

30 On the relationship between Loos and Wittgenstein, cf. (2006) JANIK, Allan, Assembling Reminders, Santérus Academic Press, Estocolmo, pp. 163-182.

31 (1962) LOOS, Adolf, Sämtliche Schriften, vol. 1, Herold, Viena, p. 102.

32 (1913) LOOS, Adolf, "Regeln für den, der in den Gebirgen baut", Der Brenner 4, no. 1, pp. 40-1.

33 The Aristotelian theory of gravity states that all bodies move towards their natural place. Those whose natural place is in the centre of the earth fall towards it and those whose natural place is in the heavenly spheres move away from the centre of the earth towards heaven and the moon.

34 We believe that Schiele may had been inspired by Egyptian "block statues" (which bring 
together body, arms and legs). Given Schiele's well-known interest on Egyptian art and his tendency to help himself from external images - generally taken from books either from his own library or from those of friends- for his artistic project (for instance, the influence of Hokusai's The great wave on Schiele's Mountain Torrent (Waterfall) is obvious; in fact, Schiele had a very good reproduction of the Japanese work in his own library, cf. (1904) PERZYNSKI, Friedrich, Hokusai, Delhagen \& Klafing, Leipzig, p. 83 - so it is not surprising. Furthermore, the artist had access to Gaston Maspero's book on Egyptian art so successful in his time ((1913) MASPERO, Gaston, Geschichte der Kunst in Ägypten, Julius Hoffmann, Stuttgart), where there are some reproductions of this kind of statues. The book belonged to August Lederer's library, a good friend of Schiele. The artist wrote down the title of the book in one of his sketchbooks (cf. 4. Sketchbook, 1912-13/ Albertina, ESA 318 Nr. 2 ).

Body and seat seem to melt in these statues. This is especially obvious if the more conventional seated statues brought together by Maspero are taken into consideration. The cube where the torso and the extremities melt is similar to the seat where the more conventional statues are seated. The cube could be interpreted as the fusion of extremities and torso mentioned above or as a seat supporting only a head. It is worth pointing out the importance of chairs in Egyptian tradition. Let's remember that Isis means seat or throne. The goddess Isis is the incarnation of the Egyptian throne. She and her husband and brother, Osiris, were the original rulers. Furthermore, she is considered the mother of Horus, the first Egyptian king and, therefore, mother of the following Pharaohs.

The similarities between the stiffness of the extremities of the Egyptian statues and that of Schiele's figures are also remarkable. Furthermore, many of these statues do not have their superior extremities, as the Königin Nefret (Cairo Museum, image no. 217 in Maspero's book). They seem to be mutilated, as many of Schiele's figures.

On the other hand, the influence of standing Egyptian statues on the canvas The Virgin is obvious: the arms on the side, stuck to the body and stretched, the closed hands, one foot more to the front than another and the frontal position of the figure. (We owe our last remark to our conversations with Dr. Johann Thomas Ambrózy. We are also very thankful to him for his information about the book on Hokusai which Schiele possessed).

35 The mother's austere clothing is counteracted by the children's dresses, for whose decoration Schiele borrowed traditional motifs. Schiele already introduced this aesthetics in a similar drawing from 1915 used as a sketch for the design of a bag for Edith: 'Mother with Children, Flanked by Toys and Ornaments' (K D1799). Schiele's predilection for rural motifs supports the difference between Klimt and our artist that we established in the footnote no. 23.

36 The backs could be a consequence of the shadows projected by the figures on the wall. However, these shadows are brighter than the background, as if a light would be projecting itself over each figure. As all this happens against a dark background illuminated in three different moments.

37 The sketch we are referring to is in the twentieth page of what is known as the eighth sketchbook of the artist (1989) NEBEHAY, Christian M. (ed.), Egon Schiele. Von die Skizze zum Bild. Die Skizzenbuchen, Verlag Christian Brandstätter, Vienna, p. 205). If the panting and the sketch are compared, it is hard not to agree on the artist's magnificent capacity for simplification, since all the painting is contained in an extremely simple drawing.

38 Loos, Sämtliche Schriften, vol. 1, 277. 